\title{
RESEARCH UNIVERSITIES AND REGIONAL HIGH-TECH FIRM START-UP AND EXIT
}

\author{
DAKSHINA G. DE SILVA and ROBERT MCCOMB*
}

\begin{abstract}
If localized knowledge spillovers are present in the university setting, higher rates of both start-up and/or survival would be observed in areas that are geographically proximate to the university. Using a detailed industry data set for Texas for 1999:3-2005:2, we analyze start-up and exit rates for high-tech firms. Based on a Poisson quasimaximum likelihood estimation, we find evidence that the level of $R \& D$ and proximity of a research institution positively affects the likelihood of technology start-ups. However, using both the Cox proportional hazards model and Kaplan-Meier approach, our results suggest that geographic proximity to knowledge centers does not reduce hazard rates. (JEL R12, R53, O18)
\end{abstract}

\section{INTRODUCTION}

During the decade of the 1990s, a significant level of firm start-up activity was observed in the newly emerging high-technology industries. This activity tended to be concentrated in relatively few locations such as Silicon Valley in California, the Route 128 corridor in Boston, and the I-35 corridor in Texas. As the regional employment dynamism and relatively high incomes associated with these new technology firms were widely coveted by regional policy makers, regional economic development interests focused on initiating or attracting hightech industrial "clusters" by looking to exploit the presence of correlates. ${ }^{1}$ Chief among these correlates has been the presence of a research university or institution, or a broader research complex.

In this article, we seek to estimate the effect of federally funded R\&D in universities and

*We would like to thank Hojin Jung and Anita Schiller for their skillful research assistance and the Texas Workforce Commission for providing the data. We are also indebted to Georgia Kosmopoulou, George Deltas, Geoffrey Hewings, IIOC 2007 Conference participants, and two anonymous referees for valuable comments and suggestions.

De Silva: Associate Professor, Department of Economics, Texas Tech University, Lubbock, TX 79409. Phone (806) 742-2201, Fax (806) 742-1137, E-mail dakshina.desilva@ttu.edu

Mccomb: Associate Professor, Department of Economics, Texas Tech University, Lubbock, TX 79409. Phone (806) 742-2201, Fax (806) 742 1137, E-mail robert.mccomb@ ttu.edu

1. For a description of the cluster concept as adopted by economic development practitioners, see Porter (1998). related research complexes in Texas on the likelihood of high-technology firm entry and survival. By restricting the analysis to Texas, we control for state-specific conditions across counties that influence the variables of interest and gain fully disclosed access to a highly detailed industry data set at the 6-digit level of the North American Industrial Classification System (NAICS).

Previous researchers have considered the question of the effect of university research on the regional economy. We are, however, unaware of any previously published paper that analyzes hazard rates of firms in terms of geographic proximity to knowledge generators.

As Nelson (1986), Jaffe (1989), Acs, Audretsch, and Feldman (1992, 1994), Acs, Anselin, and Verga (2002) and Fischer and Varga (2003) point out, it is quite plausible that the presence of a research university can make locally specific contributions to the

ABBREVIATIONS
BEA: Bureau of Economic Analysis
BLS: Bureau of Labor Statistics
DM: Dirichlet-Multinomial
EIN: Employer Identification Number
NAICS: North American Industrial Classification
System
MSA: Metropolitan Statistical Area
PQML: Poisson Quasi-Maximum Likelihood
$\quad$ Estimator
QCEW: Quarterly Census of Employment and Wages
SIC: Standard Industrial Classification


level of commercial innovation in its region. ${ }^{2}$ The university provides geographically specific access to resources such as libraries, faculty, and a ready pool of graduates at all levels. Research universities and institutions conduct basic research, that is, create knowledge, with the purpose of diffusing the knowledge they create. New knowledge that spills over most readily into the locality should result in localized private sector innovation. Moreover, universities increasingly seek means by which to facilitate faculty start-ups and to enhance access to university resources to support regional entrepreneurs. ${ }^{3}$ Although universities can be the sources of direct spin-offs in the form of startups, this impact seems to be moderate and relatively recent. The Association of University Technology Managers reports that 462 new high-technology companies based on academic discovery were formed in 2004 by 191 institutions, up $23.5 \%$ from $2003 .{ }^{4}$ This only represents an average of somewhat more than two start-ups per institution. In Texas alone in 2004, there were 787 start-ups in the high-technology activities.

If there is a geographic component to diffusion of knowledge, rapid innovation of new knowledge will enhance the economic value of geographic proximity to the knowledge production location. Moreover, given the publicly funded nature of university research, spillovers may be relatively more available from universities than private sector firms conducting similar R\&D. Jaffe (1989) and Jaffe, Trajtenberg, and Henderson (1993) find evidence of localized knowledge spillovers from universities. In particular, they find that the presence of a university positively affects the local or regional level of patent activity. Anselin, Varga, and Acs (2000) find evidence that university spillovers are specific to certain industries. For example, their results suggest the strong presence of spillovers in the case of electronics but not in drugs and pharmaceuticals (at the 2-digit SIC level). Mansfield (1995) also finds evidence that the level of university R\&D expenditures and quality of relevant faculty are important to industrial innovation in technology industries (at the statewide level). He also recognizes the importance of

2. Also see Audretsch and Feldman (1996) where they examined the link between knowledge spillovers in an industry and geography of innovation and production.

3. For a survey of university technology transfer efforts, see Paytas, Gradeck, and Andrews (2004).

4. See AUTM 2004 Licensing Survey. the nearby presence of other firms in the same industry.

Zucker, Darby, and Brewer (1998) stress the importance of basic research and the growth and location of human capital to the location of biotech start-ups. They place an emphasis on the location of highly productive university faculty in the life sciences. Looking at the data for 183 functional economic areas (defined by the BEA) for the period 1976-1989, they find that the number of both highly productive faculty and top-quality research institutions had a positive and significant effect on the geographical distribution of the stock of biotech firms in 1990. They also find that the number of faculty "stars" had a positive, but diminishing effect on the number of biotech start-ups over the period. They underscore the importance of start-ups to the growth and geographical distribution of the biotech sector. As they note, the biotech industry went from being practically non-existent in 1975 to over 700 firms by 1990 . In a similar way, the rapid pace of innovation in the new high-technology activities that emerged in the 1990s appears to have been expressed in high rates of start-ups and exits.

Although we might posit that the presence of local spillover effects from university research should contribute to higher levels of technology start-up activity and lower rates of exit in more proximate geographic regions, we cannot necessarily disallow other possibilities for the localized influence of the universities and research centers. It may be that the presence of a large university is a driver for the social and cultural climate that creative individuals require. In such a case, it is not just the technical knowledge that is created and locally diffused by the university, but also the aura of the university that matters in the attraction or retention of creative technology entrepreneurs. More generally, the higher the quality of the social, recreational, and cultural environment, the more attractive the area should be to entrepreneurs surveying locales in which to start their firm.

Similarly, there may be a positive relationship between the size of the research institution and the quality of the pool of recently trained individuals. This would most certainly be the case for individuals undertaking graduate study. If these graduates are seeking a means to earn a living within their alma mater's community, this would be an additional channel for localized knowledge spillover. Better trained graduates 
who retain personal linkages to the research center are better prepared to initiate a start-up.

Although the presence of university research activities may be a necessary condition for the presence of a significant cluster of hightech private sector activity, it clearly is not sufficient. Examples of relatively undeveloped regional economies that host notable research universities are not difficult to find. Indeed, although much of the research to date has found a positive effect of university $R \& D$ on growth of high-technology industrial activity, the estimated effect is generally rather modest. There clearly are other important determinants.

In an approach similar to our article, Woodward, Figuerido, and Guimarães (2006) consider the effect of university R\&D in science and engineering on the appearance of new high-tech establishments across all contiguous counties in the United States from 1997 through 2000. Using Census data at the 3-digit SIC level to identify high-tech entrants, they analyzed a set of 31 "R\&D intensive" industries. Controlling for factor costs, urbanization and localization economies, and cultural and natural amenities, they find a significant effect of university $R \& D$ on the probability of a firm locating within close proximity of the research university. However, the effect is slight. They conclude that a $\$ 1$ million increase in university $R \& D$ increases the probability of a new establishment by less than $0.1 \%$.

Abramovsky, Harrison, and Simpson (2007) investigate the effect of university $R \& D$ on the location choices of R\&D-performing firms in Great Britain across 111 postal zones. Using a quality index for university research departments, the authors construct a weighted-average index for all universities and aggregate measures of the departmental-level research quality in ten research fields in each of the regions. Looking at the geographic distribution of both existing establishments and the number of new entrants of R\&D-performing firms over the period 2001-2003 for six product groups, the authors find little empirical support for the proposition that the number or quality of research universities had a positive effect on the location choices of R\&D-performing firms. Oddly enough, where the universities appear to have some relevance to location decisions, they are lower tier, not top tier, research institutions. Agglomeration effects, industryspecific localization economies and workforce educational characteristics appear to play important roles.

The results of our analysis suggest there is persuasive evidence that the presence of a research institution and the size of its research enterprise affect the probabilities of technology start-ups in Texas counties. On the other hand, there is little support for the hypothesis that geographic proximity to knowledge centers reduces hazard rates. This latter finding is not necessarily inconsistent with the presence of localized spillovers. If local barriers to entry are low, positive spillovers would attract entry up to the point at which the private benefits from the shared, unpriced inputs are competed away. Thus, one would expect to see higher local levels of entry, but mortality rates that are similar to the broader industry. ${ }^{5}$

One concern that might arise with the analysis of start-up firms is the possibility that levels of federal R\&D funding and regional hightechnology industry development are endogenously determined. To clarify the discussion on this point, a distinction must be drawn between the distribution of existing industrial activities and the distribution of start-ups in the given industries during a given period. For example, if industry influenced funding opportunities for the local university, the endogeneity question would be critical to a study of the effect of university $R \& D$ on the existing distribution of industrial activity.

Abramovsky, Harrison, and Simpson (2007) address this problem in their investigation of university research quality and industry location by also analyzing the distribution of start-ups. They control for the number of establishments in the particular industrial activity in the region. Since by definition, current start-ups did not exist at the time the R\&D funding decisions were made, they can pose no causality. Woodward, Figuerido, and Guimarães (2006) take this same approach and do not register concerns about endogeneity. The analysis in this article

5. We are grateful to an editor of this journal for motivating our thinking on this point. A slightly different approach to this finding might be that, when localized technology spillovers are present and start-ups are thus facilitated in the same or very close substitute product space, there would be more intense competitive pressure for local firms to rapidly commercialize the given $R \& D$ and be first to market. This may result in less investment in proof-ofconcept and less thoughtful market strategy. Overall, the presence of more and closer substitutes would effectively increase the riskiness of the local firms that share the unpriced input. The net effect of spillovers on failure rates, under conditions of easy entry, may then be a wash. 
focuses on start-ups within a fixed effects model that controls for local heterogeneities across a broad set of observed variables.

Section II describes the data set; Section III reports the results of the empirical analysis; and Section IV summarizes the main findings of the study.

\section{DATA}

We obtained firm-level data for Texas from the Quarterly Census of Employment and Wages (QCEW) from the Texas Workforce Commission. This data set provides firm-specific monthly employment and quarterly total wages reported by establishment as required under the Texas unemployment insurance program. Each record includes the specific location (address) of the establishment, business start-up date (the date on which unemployment insurance liability begins), and the relevant 6-digit NAICS code. Each record includes each firm's unique employer identification number (EIN). Furthermore, separate establishments (branches or franchises) of the same firm are separately identified and reported in separate records. This panel data set is comprised of observations from Q3:1999 through Q2:2005. It should be pointed out that the authors obtained these data under an agreement of confidentiality and disclosure of the actual data is subject to certain restrictions.

The focus of this analysis is on the technology or knowledge-intensive industries. Definition of the technology sector is relatively easy in the abstract, but difficult in reality. There are industries that commercialize new or adapted technologies and industries that are relatively more dependent on applications of technology to remain competitive. This article adopts the definition of technology industries as developed by Paytas and Berglund (2004). Their classification identifies technology employing industries as those industries in which employment in technology occupations is at least three times the national average. ${ }^{6}$ Primary technology generating industries are defined as those industries in which R\&D expenditures per employee and the proportion of scientists and engineers in the workforce exceed the national average.

6. This is based on the BLS Occupational Employment Statistics at the 3-digit level of aggregation and a subset of occupations designated as science and engineering intensive by Chapple et al. (2004).
Secondary technology generating industries are those that only meet one of the two criteria.

Although BLS occupational data are only aggregated at the 4- and 5-digit NAICS, Paytas and Bergland translate these into 4- and 6-digit NAICS industry classes. This yields a list of primary and secondary technology generators, and a list of technology employers at 6-digit NAICS codes. We use these NAICS-6 codes to identify technology firms. In our data set, we have more than 17,000 technology firms and 900,000 total observations. From these, we identify the numbers of start-ups, incumbents, and exits (by NAICS code) for a given county for a given fiscal year. Figure 1 illustrates the concentration of these high-tech start-ups in the metropolitan areas of Texas along Interstate 35. One can also note a sprinkling of high-tech firms across the less urban areas of the state.

Using the QCEW, annual county employment in each 6-digit NAICS code is computed as the average monthly employment level for the year. The year is defined as the four consecutive quarters beginning with the third quarter in each calendar year. To arrive at annual average income for each industry, we compute total average income within each 2-digit NAICS for the year. ${ }^{7}$ Although it would be ideal to have a narrower definition of industry for purposes of average income, it is not practical as many counties have no employment, and thus no income, at the more detailed industry level. Working at the NAICS-2 provides a non-zero datum on factor cost for each county for every industry.

We are interested in the likelihoods of startups and firm survival given geographic proximity to knowledge centers. Hence, the number of start-ups and exits by NAICS code for a given county for a given year are the units of observation. There are only fifty industries being tracked. Four high-tech industries at 6-digit NAICS were omitted as there was no variation over the period of this analysis (Table S1, Supporting Information). We have

7. Even at the NAICS-2 levels containing the high-tech industries, some counties have zero employment. In these cases, bearing in mind that we are trying to capture wage and income levels in higher skill activities, we compute an average wage using NAICS 31-33 (Manufacturing), 51 (Information), 52 (Finance and Insurance), 54 (Professional, Scientific, and Technical Services), 55 (Management of Companies and Enterprises), 61 (Educational Services), and 62 (Health Care and Social Assistance). A relatively large share of employment in these industries requires a bachelor's degree. 
FIGURE 1

High-tech Firms and Research Institutions in Texas

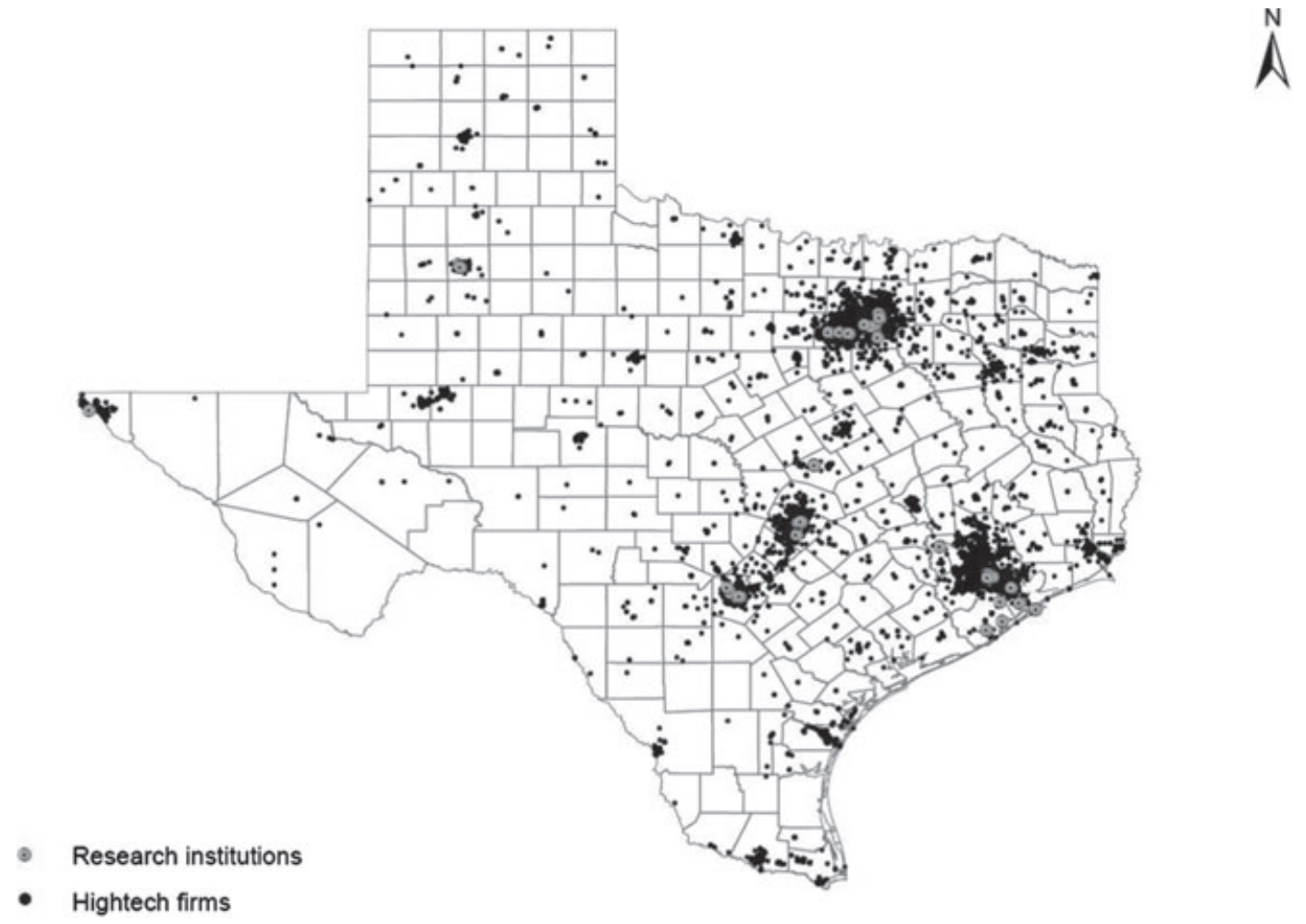

then 76,200 observations over the 6 year period 1999:3-2005:2. ${ }^{8}$

The appearance of a new EIN is used to define market entry and disappearance of the EIN is treated as an exit during any given period. Exits, in this context, may not signal business failure as the initial objective of many technology entrepreneurs (and their venture capitalist backers) is to build a firm with the intent of selling the firm within a 1- to 3-year time frame to a larger, incumbent firm. In some cases, this sale will result in the disappearance of the original firm from the data set if the firm is merged into another establishment, re-launched as a new firm, or relocated outside the county. Although this may complicate the analysis of the effect of university $R \& D$ on firm failure rates, there

8. Four industries at 6-digit NAICS were omitted as there was no variation in start-ups over the period of this analysis (Table S1), so there are only 50 industries being tracked. The total number of observations is therefore 50 industries multiplied by 254 counties multiplied by 6 years (1999:3-2005:2) or a total of 76,200 observations. is no reason to suspect a priori that the proportions of firms that either fail or sell should vary systematically, ceteris paribus, by geography. Therefore, we assume that the variability across counties of firm failures is directly proportional to the variability of firm exits from the data set. This method to identify exits has been used elsewhere in the economics literature. For example, Baldwin and Gorecki (1991), Dunne, Robert, and Samuelson (1988, 1989a, 1989b), Dunne, Klimek, and Roberts (2005) used this definition of exit in their analyses of firm entry and exit.

Table 1 provides basic summary statistics for start-ups and incumbents. On average, for a given 6-digit NAICS code, there are about 0.7 incumbents and 0.07 new firms per county per year. When considering the number of exits, on average, there are about 0.11 exits by incumbent firms per county per year and 0.06 by startups. There were no start-ups or incumbents in many counties during the period of this study. Looking only at counties in which high-tech 
TABLE 1

Start-ups' and Incumbents' Summary Statistics

\begin{tabular}{|c|c|c|c|c|c|c|}
\hline \multirow[b]{2}{*}{ Variable } & \multicolumn{2}{|c|}{ All Counties } & \multicolumn{2}{|c|}{ MSA Counties Only } & \multicolumn{2}{|c|}{ Knowledge Center Counties } \\
\hline & Start-ups & Incumbents & Start-ups & Incumbents & Start-ups & Incumbents \\
\hline Average number of firms & $\begin{array}{c}0.065 \\
(0.993)\end{array}$ & $\begin{array}{c}0.683 \\
(11.071)\end{array}$ & $\begin{array}{c}0.205 \\
(1.791)\end{array}$ & $\begin{array}{c}2.123 \\
(20.027)\end{array}$ & $\begin{array}{c}1.186 \\
(4.694)\end{array}$ & $\begin{array}{c}12.347 \\
(53.543)\end{array}$ \\
\hline Average number of exits & $\begin{array}{c}0.063 \\
(1.393)\end{array}$ & $\begin{array}{c}0.110 \\
(2.613)\end{array}$ & $\begin{array}{c}0.200 \\
(2.522)\end{array}$ & $\begin{array}{c}0.349 \\
(4.735)\end{array}$ & $\begin{array}{c}1.211 \\
(6.796)\end{array}$ & $\begin{array}{c}2.126 \\
(12.833)\end{array}$ \\
\hline Average number of employees & $\begin{array}{c}39.904 \\
(363.975)\end{array}$ & $\begin{array}{c}49.810 \\
(346.560)\end{array}$ & $\begin{array}{c}41.314 \\
(373.666)\end{array}$ & $\begin{array}{c}52.019 \\
(356.705)\end{array}$ & $\begin{array}{c}42.090 \\
(389.482)\end{array}$ & $\begin{array}{c}59.982 \\
(401.247)\end{array}$ \\
\hline Average income & $\begin{array}{c}5,185.20 \\
(5,263.73)\end{array}$ & $\begin{array}{c}5,493.39 \\
(7,693.12)\end{array}$ & $\begin{array}{c}5,251.04 \\
(5,349.74)\end{array}$ & $\begin{array}{c}5,604.26 \\
(7,871.16)\end{array}$ & $\begin{array}{c}5,502.64 \\
(5,792.92)\end{array}$ & $\begin{array}{c}5,866.79 \\
(7,101.32)\end{array}$ \\
\hline
\end{tabular}

Note: Standard deviations are in parenthesis.

firms are located, incumbents have on average about 10 more employees per month than startups. Also, monthly income for start-ups and incumbents differs significantly. Start-ups pay about $\$ 300$ per month less than established firms. For metropolitan statistical area (MSA) counties, the average number of incumbents is 2.1 and the average number of start-ups is 0.2. In the case of knowledge center counties, the average numbers of incumbents and start-ups are 12.3 and 1.2, respectively. Nevertheless, in both the MSA and knowledge center counties, the differences in numbers of employees and wages between start-ups and incumbents are similar to what we observe for all counties. ${ }^{9}$

We proxy the level of research activity within the knowledge centers by using total federal research awards by federal fiscal year to Texas universities and research institutions for science and engineering $R \& D$. This represents the magnitude of potential knowledge spillovers from research universities and institutions. Data on university R\&D expenditures were obtained from the National Science Foundation (NSF). These expenditures are available by recipient institution by granting agency for each year of our analysis.

Although the NSF provides research funding by institution that is identified by granting agency or departmental source, that is, DoE, EPA, DoD, we aggregate total federal awards by geographically distinct institution. System campuses are thus scored geographically separately. There is one significant exception to this geographic separation; the reported totals for Texas A\&M (the state land grant institution) are partially aggregated in "Texas A\&M,

9. All ten knowledge center counties are MSA counties, but not all MSA counties are knowledge center counties. all campuses," although the Texas A\&M Health Sciences Center is reported separately. Without additional specifics, we attribute the total awards to Texas A\&M, all campuses, to the main campus in College Station.

Total external R\&D funding is calculated on a county-by-county basis by adding all awards to all universities within a county. As our objective was to identify universities and research centers that actively conduct $R \& D$, we define a knowledge center as a county receiving at least \$10 million (in 1999 dollars) in federal R\&D funding during any federal fiscal year between 1995 and 2003. ${ }^{10}$ This bar captures the great bulk of externally funded $R \& D$ in Texas universities and medical research institutions. It reduces the 254 counties in Texas to ten counties, each deemed to be a knowledge center. Table S2 identifies the academic institutions in these counties and their locations are also mapped in Figure 1. Harris County (Houston) has consistently received the largest amount of federal funding followed by Travis (Austin) and Dallas (Dallas) counties. Table 2 presents the total funding of these selected counties.

To capture the local workforce characteristics relevant to high-tech activities, we considered two alternative formulations. One alternative is the share of county population with bachelor's degree or higher as reported by the U.S. Census Bureau in the year 2000 decennial census. These data are reported for only 116 of the 254 Texas counties, i.e., counties that are included in either a metropolitan or micropolitan statistical area. If we used the rural average of $13.8 \%$

10. We set this requirement in nominal dollars although R\&D expenditures are deflated to $1993: 3$ in the regression analysis. As is evident from Table 2, deflating R\&D expenditures to 1999:3 will not change the set of research centers. 
TABLE 2

Funding by County

\begin{tabular}{|c|c|c|c|c|c|c|c|c|c|}
\hline \multirow[b]{2}{*}{ County } & \multicolumn{9}{|c|}{ Fiscal Year } \\
\hline & 1995 & 1996 & 1997 & 1998 & 1999 & 2000 & 2001 & 2002 & 2003 \\
\hline Bexar & 132,240 & 143,603 & 123,456 & 131,522 & 131,591 & 166,159 & 180,733 & 168,448 & 202,852 \\
\hline Brazos & 169,888 & 147,948 & 160,234 & 131,986 & 180,576 & 187,164 & 239,402 & 234,820 & 258,288 \\
\hline Dallas & 193,532 & 378,111 & 406,623 & 408,488 & 328,480 & 258,363 & 300,453 & 633,820 & 516,580 \\
\hline Denton & 8,175 & 6,509 & 6,843 & 7,848 & 18,030 & 19,569 & 23,471 & 22,420 & 29,283 \\
\hline El Paso & 21,672 & 35,399 & 32,564 & 16,589 & 35,209 & 20,900 & 25,856 & 30,721 & 27,733 \\
\hline Galveston & 85,920 & 93,985 & 102,311 & 101,200 & 162,139 & 179,442 & 197,201 & 226,632 & 356,799 \\
\hline Harris & 602,505 & 647,880 & 607,783 & 736,785 & 752,151 & 915,044 & $1,107,989$ & $1,317,971$ & $1,344,938$ \\
\hline Lubbock & 18,067 & 20,765 & 22,934 & 27,828 & 27,975 & 38,817 & 42,006 & 38,814 & 52,449 \\
\hline Tarrant & 82,676 & 37,346 & 34,569 & 26,283 & 15,939 & 11,445 & 14,033 & 23,051 & 28,896 \\
\hline Travis & 280,091 & 351,267 & 271,068 & 258,116 & 273,261 & 316,759 & 364,421 & 305,650 & 505,583 \\
\hline
\end{tabular}

Note: In thousands of 1999:3 dollars.

for the remaining 138 counties, there would be no variation in this variable for the majority of counties over the period of the analysis. We prefer to use the share of county population between the ages of 20 and 44. These estimates are available annually (year 2000 is actual census data) for all counties from the Census Bureau's Annual Population Estimates. This variable serves as a proxy for the technological savvy of the workforce and assumes younger workers are more comfortable with rapidly evolving technologies. This should also reflect the relative labor force potential for hightech entrepreneurial activity insofar as much of the high-tech boom was reputed to be driven by relatively young entrepreneurs.

As Woodward, Figuerido, and Guimarães (2006) suggest, cultural and natural amenities are important to industrial attraction and skilled workforce retention. As climatic conditions do not vary substantially across the state, we focus on local cultural and recreational amenities as the relevant variable. This measure is intended to capture the influence of the locality's urban amenities on its attractiveness. Although natural amenities may be valued, urban amenities are both more immediate and relevant to day-today life for full-time employed individuals. ${ }^{11}$ To measure the relative local presence of these

11. Our measure of amenities is intended to capture greater diversity in localized consumption amenities that may be available, ceteris paribus. Glaeser, Kolko, and Saiz (2001) refer to the availability and diversity of non-tradable goods such as local cultural and entertainment opportunities as a critical urban amenity to explain urban growth. It might be asked if one should expect high rates of manufacturing growth to outstrip rates of growth in employment in cultural or recreational amenities and result in amenities, we compute the share of county employment in NAICS 71, Arts, Entertainment, and Recreation, and NAICS 721110 (hotels and motels), 722110 (full service restaurants), and 722410 (drinking places, alcoholic beverages) as reported in the QCEW data set. These NAICS 72 activities also reflect the scope of the locality's amenities for business travelers and informal business and social interaction.

To account for factor costs, we use the yearly median rural land price in each of 33 land market regions in Texas for the counties comprising the region as reported by the Texas A\&M Real Estate Center. As a second measure, we use average wages paid in the entering or surviving firm's industry at the 2-digit NAICS as described above. The county unemployment rate for each year, as reported by the Texas Workforce Commission, is also included to provide an indication of the overall economic conditions in the county. ${ }^{12}$ Lastly, all data reported in nominal dollars are deflated to 1999:3 dollars.

declining shares in these latter activities. If so, the contribution of these amenities to manufacturing growth would be under-estimated. But the literature has uniformly found that the demand for these amenities (and their diversity) is income elastic. So these shares should increase with the growth of high-tech, high income manufacturing activities. As we are looking at start-ups, not growth, our argument is based on the greater demand for consumption diversity of urban non-tradables by higher skilled, highly educated workers and high-technology firms who are surveying potential places to locate. Carlino and Saiz (2008) make this point.

12. The TWC unemployment rate is the average rate for the calendar year. We average consecutive years beginning with year 1999-2000 as that best overlaps our definition of a year as running from third quarter through second quarter of the following calendar year. 
In the next section, we empirically model the relationship between the levels of federally funded R\&D and the rates of technology firm start-up and survival pattern of technology firms.

\section{EMPIRICAL ANALYSIS}

\section{A. Research and Development Expenditures and Entry}

An important feature of this analysis is the relatively high degree of both geographical and industrial detail that is utilized. As the size of the geographical unit of analysis increases, the ability of the model to incorporate and detect the effects of localized factors decreases. For example, local agglomeration economies, local labor force characteristics, and the availability of cultural and recreational amenities probably play an important role in industry attraction but are increasingly obscured as the geographic area and diversity broadens. By the same token, the greater the level of industry aggregation, the more likely it is that informative industry characteristics are lost. Within a 2- or 3-digit SIC or NAICS code, industries can be quite heterogeneous in terms of inputs and relevant output markets. The geographical area for this analysis is the county level which, in Texas, is relatively small. Counties are mostly square (Figure 1) and, on average, only 44 miles across the diagonal. The industrial data at NAICS-6 are also highly detailed.

We first consider the number of new start-ups in the technology industry in Texas as a function of distance from knowledge centers and the level of external funding at these knowledge centers. As noted above, this level of funding is a proxy for the "size" of the knowledge center or, alternatively, for the amount of knowledge being produced. As we are examining the number of start-ups, we employ a count data model. We use a fixed effects Poisson model using 6-digit NAICS codes as a group variable. This allows us to control for unobservable heterogeneities at NAICS levels.

A standard Poisson model assumes equality between the mean and variance of the dependent variable. Specification tests for over-dispersion reject the standard Poisson as the appropriate distribution for the data in this study. In such cases, researchers have often turned to the negative binomial model where the assumed distribution for the dependent variable exhibits over-dispersion. Nevertheless, in contrast to the standard Poisson, the Poisson quasi-maximum likelihood estimator (PQML) has an important property which, we believe, makes it appropriate and preferable in this context. It can be shown that PQML estimates are consistent under quite weak assumptions (Gourieroux, Montfort, and Trognon 1984a, 1984b). In particular, unlike the standard Poisson estimation, the PQML estimation does not assume that the data are distributed with the mean equal to the variance of the event count. ${ }^{13}$ The data do not have to come from a Poisson process at all, and may be either under or over-dispersed. All that is required for PQML consistency is that the conditional mean function be correctly specified. ${ }^{14}$

As we believe our model meets this requirement, we use the fixed effects PQML estimator to produce our baseline results. ${ }^{15}$ In this case, the estimated coefficients are identical to fixed effects Poisson regressions but the standard errors are adjusted for over-dispersion. We report robust standard errors clustered by NAICS codes. Our dependent variable is the number of start-ups $(y)$ for a given county $(i)$ for a given year $(t)$ by 6-digit NAICS code $(\alpha)$. The basic model is as follows:

$$
\begin{aligned}
f\left(y_{i t} \mid \mathbf{X}_{i t}, \alpha_{i}, \beta\right) \\
=\Pi_{t=1}^{T} \exp \left[-\alpha_{i} \exp \left(\mathbf{X}_{i t}^{\prime} \beta\right)\right] \\
\quad \times\left[-\alpha_{i} \exp \left(\mathbf{X}_{i t}^{\prime} \beta\right)\right]^{y_{i t}} / y_{i t} !
\end{aligned}
$$

Then the conditional mean is:

$$
E\left(y_{i t} \mid \alpha_{i}, \mathbf{X}_{i t}\right)=\exp \left(\gamma_{i}+\mathbf{X}_{i t}^{\prime} \beta\right)
$$

where $\gamma_{i}=\ln \left(\alpha_{i}\right)$.

The independent variables $\mathbf{X}$ can be classified into four main groups: $x_{1}$ represents knowledge spillovers, $x_{2}$ controls for county $i$ 's (herein base county) characteristics for a given year for a given industry, $x_{3}$ controls for the average characteristics of county $j$ (contiguous neighbor

13. Also note that Guimarães (2008) shows that the conditional maximum likelihood estimator of the negative binomial with fixed effects does not necessarily remove the individual fixed effects in count panel data. This will happen only if the number of groups is at least 1,000 with more than 20 periods per group.

14. The negative binomial model, by contrast, is only consistent if the conditional distribution of the dependent variable is in fact a negative binomial. Thus, the potential benefit from preferring the negative binomial over Poisson, that is, increased efficiency if the data are over-dispersed, must be balanced against the more restrictive conditions that need to be met to ensure consistency.

15. For a more detailed discussion of this reasoning, see Wooldridge (2002) and Cameron and Trivedi (2005). 
of base county $j$ ) for a given year for a given industry, and $x_{4}$ are time dummies to identify fiscal years. ${ }^{16}$ Every county in Texas is treated as a base county in the analysis, and each is considered in relation to its distance from the relevant knowledge center county.

To account for the decay of the spillover effect as distance to the knowledge center increases, we deflate total annual R\&D funding in the knowledge center county by distance between base county and knowledge center county. This is carried out by computing the ratio of the knowledge center's total R\&D funding to distance between the base county and the knowledge center county. A ratio is computed for all counties relative to all knowledge centers. The distance between counties and the knowledge center county is calculated as the distance in miles between the latitude and longitude of each county seat. Note that this construction results in a relatively rapid decay in federally funded R\&D expenditures as the distance increases between base counties and the knowledge center county. In cases where the base county is also the knowledge center county, we assume the county is square, and take half the distance of the diagonal from opposite corners of the county. This avoids the problem of zero distance in the denominator of the spillover ratio for the knowledge center in these cases.

Each county is then assigned to the region of the knowledge center for which the R\&D spending to distance ratio is greatest. The set of all Texas counties is thereby partitioned into 10 nonoverlapping "spillover" regions in each period.

The question of the appropriate lag in $R \& D$ expenditures is also important. If knowledge spillovers from federally funded research are present, there will clearly be a time element involved. External funding for research in any given year supports that year's research. Although it is clear that most scientific and engineering $R \& D$ projects are ongoing and take place over the course of several years, the research carried out in any given year will generally not be available for commercial purposes until at least the following year. Thus, whether it is ongoing research or newly established research initiatives that are being funded by federal support, the effect can reasonably be expected to occur in the following or several

16. There are five time dummies for the 6 fiscal years of the analysis, the initial year being omitted. successive periods. Therefore, we lag the R\&D funding by 1-4 years in order to address the time element in knowledge diffusion.

Table 3 provides a sense of the geographic size of the ten spillover regions in terms of the average minimum distance between the base county and its knowledge center county. It also includes the average normalized spillover size of each region by lagged period. Harris, Dallas, and Travis counties have the highest funding per mile.

When controlling for base county characteristics, we first use the past year's $(t-1) \log$ of average monthly employment by 6-digit NAICS code for start-ups and incumbents at the county level. ${ }^{17}$ These variables control for industryspecific localization economies due to the presence of specific labor resources, kindred firms, and a larger pool of potential entrepreneurs within the existing industry base. Experience working within an industry should enhance an entrepreneur's ability to enter that or a similar industry.

The possibility that the levels of $R \& D$ funding might depend on the local industrial presence raises the question as to the appropriateness of using both the level of research expenditures and measures of the size of the local industry on the right hand side of the equation. It is therefore worth pointing out that there is little prima facie evidence from Texas during the period of this analysis that these variables are correlated. ${ }^{18}$

We also use year $t-1$ 's number of startups, and the number of exits by new firms and incumbents by 6-digit NAICS code. This controls for the "entrepreneurial culture" in the

17. The actual variable is employment plus one. As a referee pointed out, if no firms in an industry are present in the previous period, exits must necessarily be zero. This is a different circumstance than zero exits in a county that hosts one or more firms in the industry, although both are coded as zero. One method of controlling for this distinction would be to introduce a dummy variable for the absence of the industry in the previous period. An alternative approach is to include existing employment (or $\log$ of existing employment plus 1) in the industry in the previous period. With either approach, the variable takes a value of zero if no firms are present in the county at the start of the period and a positive value if firms are present. As the simple correlation between the dummy variable and the $\log$ of incumbent employment is 0.845 , there is very little change in explanatory power associated with one specification over the other. We estimated the model separately with both specifications and observed no qualitative difference in results.

18. The simple correlation between high technology industry employment in the knowledge center county and the level of current federal funding is only 0.0749 . 
TABLE 3

Average Spillover and Distance to the Closest Knowledge Center County

\begin{tabular}{llcccc}
\hline $\begin{array}{l}\text { Knowledge } \\
\text { Center }\end{array}$ & & \multicolumn{4}{c}{ Spillover = Funding (In Thousands of Dollars)/Distance } \\
\cline { 3 - 6 } County & Average Distance & Lagged by 1 year & Lagged by 2 years & Lagged by 3 years & Lagged by 4 years \\
\hline Bexar & $224.243(106.016)$ & $1,063.84(977.35)$ & $977.77(895.59)$ & $950.83(869.26)$ & $898.26(812.51)$ \\
Brazos & $214.837(97.025)$ & $1,398.07(1,592.01)$ & $1,286.82(1,461.50)$ & $1,188.25(1,347.21)$ & $1,109.39(1,229.97)$ \\
Dallas & $217.155(105.507)$ & $2,775.09(2,818.64)$ & $2,650.35(2,679.20)$ & $2,360.26(2,225.40)$ & $2,238.96(2,181.58)$ \\
Denton & $221.808(101.041)$ & $129.84(135.17)$ & $105.68(115.48)$ & $88.56(103.11)$ & $72.09(83.26)$ \\
El Paso & $481.598(149.829)$ & $64.14(49.09)$ & $66.11(50.91)$ & $68.02(52.92)$ & $66.31(52.26)$ \\
Galveston & $297.771(149.312)$ & $999.30(1,038.60)$ & $791.43(776.63)$ & $683.08(674.04)$ & $592.19(584.49)$ \\
Harris & $289.235(145.521)$ & $6,200.73(8,710.00)$ & $5,460.49(7,746.46)$ & $4,787.60(6,670.33)$ & $4,280.00(5,864.01)$ \\
Lubbock & $275.719(135.653)$ & $223.20(277.28)$ & $194.29(240.67)$ & $176.62(222.45)$ & $153.17(192.78)$ \\
Tarrant & $207.820(96.8559)$ & $138.41(138.89)$ & $144.98(150.58)$ & $161.51(173.74)$ & $240.92(308.13)$ \\
Travis & $204.445(101.141)$ & $2,361.19(2,159.98)$ & $2,087.58(1,817.86)$ & $2,140.80(1,871.83)$ & $2,042.41(1,773.69)$ \\
\hline
\end{tabular}

Notes: Standard deviations are in parenthesis. Data based on values in Table 2 and distance in miles.

locality. Entrepreneurial culture reflects such features as the presence of serial entrepreneurs, availability of venture capital, support networks for entrepreneurs, local attitudes toward business failure, local incentive programs to stimulate entrepreneurial start-ups such as business incubation programs, and aggressive technology transfer programs at the local knowledge center that facilitate local start-ups. Similarly, when controlling for neighboring counties, we use all the variables that control for base county characteristics.

In order to account for the presence of urbanization economies, we include a dummy variable that takes the value of one for a county that is part of an MSA and zero if the county is not within an MSA. We use the 2004 MSA county list from the Texas State Data Center that includes several counties that were added to MSAs in 2003 based on results of the 2000 Census. The MSAs account for only 77 of the 254 Texas counties but contained about $86 \%$ of the state's population of nearly 21 million at the time of the 2000 Census. ${ }^{19}$ Use of the qualitative MSA variable to capture agglomeration economies seems preferable to county manufacturing or population density measures as it provides a simple means to capture regional urbanization and labor draw for counties that may be largely suburban or partially overtaken by sprawl. A dummy variable for knowledge center county enables us to control for common unobserved variables that might help to explain the location and size of both the research

19. A list of MSA counties in Texas can be found at http://txsdc.utsa.edu/tpepp/msa04_list.php institution(s) and the local private sector hightechnology activity, existing and prospective. As noted above, this common feature may simply be the qualitative impact of the presence of a university on the community. We also include the county unemployment rate for the year.

The first set of regression results are reported in Table 5(a). In column 1, we lag the funding per mile by 1 year. In columns 2, 3 and 4 we lag the funding per mile by 2, 3 and 4 years keeping the base county and neighboring county characteristics lagged by 1 year. In general, where the signs of the estimated coefficients are significant, they are also positive as would be expected if localized spillovers are important in explaining technology start-up activity. The probability of observing a start-up in the given county decreases as the distance from the knowledge center increases, all else equal.

When considering base county characteristics, the coefficients on the qualitative variables that identify counties as hosting a knowledge center and being part of an MSA are relatively large and significant. Total employment in previous start-ups in the same industry also appears to have a positive influence on entry. This suggests that the presence of an entrepreneurial culture is an important explanatory variable. Similarly, the higher the past employment in incumbent firms, the higher the rate of new entry into the market. This would be consistent with the view that employees of existing firms represent a pool of potential entrepreneurs (who prefer to start a business where they already live) and a local source of potential employees for an entrant. Both effects are also consistent with the view 
TABLE 4

Summary Statistics for the Regression Variables

\begin{tabular}{|c|c|}
\hline Variable & $\begin{array}{c}\text { Mean } \\
\text { (Standard } \\
\text { Deviation) }\end{array}$ \\
\hline Number of start-ups by industry & $0.065(0.993)$ \\
\hline \multicolumn{2}{|l|}{ Log of Funding relative to distance to county } \\
\hline Spillover lagged by 1 year & $8.442(0.804)$ \\
\hline Spillover lagged by 2 years & $8.328(0.809)$ \\
\hline Spillover lagged by 3 years & $8.237(0.799)$ \\
\hline Spillover lagged by 4 years & $8.147(0.796)$ \\
\hline \multicolumn{2}{|l|}{ Base county's } \\
\hline Knowledge center county & $0.039(0.194)$ \\
\hline MSA county & $0.303(0.460)$ \\
\hline $\begin{array}{l}\text { Log of lagged employment of start-ups } \\
\text { by industry }\end{array}$ & $0.041(0.342)$ \\
\hline $\begin{array}{l}\text { Log of lagged employment of } \\
\text { incumbents by industry }\end{array}$ & $0.189(0.753)$ \\
\hline $\begin{array}{l}\text { Lagged number of exits by start-ups by } \\
\text { industry }\end{array}$ & $0.047(1.262)$ \\
\hline $\begin{array}{l}\text { Lagged number of exits incumbents by } \\
\text { industry }\end{array}$ & $0.094(2.531)$ \\
\hline Income (in thousands) & $2.425(0.986)$ \\
\hline Amenity & $3.127(2.451)$ \\
\hline Land price (in hundreds) & $2.680(2.126)$ \\
\hline $\begin{array}{l}\text { Percentage of population between ages } \\
20 \text { and } 44\end{array}$ & $40.007(5.214)$ \\
\hline \multicolumn{2}{|l|}{ Neighboring counties' } \\
\hline $\begin{array}{l}\text { Log of lagged employment of start-ups } \\
\text { by industry }\end{array}$ & $0.080(0.407)$ \\
\hline $\begin{array}{l}\text { Log of lagged employment of } \\
\text { incumbents by industry }\end{array}$ & $0.361(0.875)$ \\
\hline $\begin{array}{l}\text { Lagged number of exits by start-ups by } \\
\text { industry }\end{array}$ & $0.047(0.777)$ \\
\hline $\begin{array}{l}\text { Lagged number of exits incumbents } \\
\text { by industry }\end{array}$ & $0.094(1.550)$ \\
\hline Amenity & $3.784(2.168)$ \\
\hline $\begin{array}{l}\text { Percentage of population between ages } \\
20 \text { and } 44\end{array}$ & $41.979(4.512)$ \\
\hline \multicolumn{2}{|l|}{ Time and business variables } \\
\hline $\begin{array}{l}\text { FY 2000-01, FY 2001-02, FY 2002-03, } \\
\text { FY 2003-04, and FY 2004-05 }\end{array}$ & $0.167(0.373)$ \\
\hline Unemployment rate (county level) & $5.551(1.926)$ \\
\hline Prime lending rate & $5.547(0.826)$ \\
\hline
\end{tabular}

that the start-ups enjoy localization economies from the presence of other firms in the industry.

The estimated coefficient on the lagged number of exits by start-ups is negative. This suggests at least two interpretations. A higher number of exits from a given industry may increase the perception of start-up risk of failure and reduce local venture capital interest in that industry. Secondly, if the higher number of exits of recently launched firms in the county is a result of weak local entrepreneurial support networks, then the location will be less attractive to new potential entrants.

Higher current average income in the industry in the county appears to increase the likelihood of observing a start-up. One reason may be that higher incomes in an industry provide a positive signal to potential entrepreneurs and attract entry into that industry. However, from the perspective of factor costs, theory would suggest a negative relationship between local labor cost and the likelihood of entry. It has, nevertheless, been generally observed that relative returns to high-skill labor grew substantially during this period of rapid growth in the technology sector. This variable may in fact be capturing the differences in occupational configurations within the NAICS-2 classification across counties. By the very definition of the high-tech sector at the NAICS-6, high-tech entrants require employees with higher technology skills than the broader class of firms within their NAICS-2. In such a case, if the specific skills they require are present in greater proportions in a given locality than elsewhere, the NAICS-2 income level in that locality should be higher. Given the importance of the presence of specific technology skills to this sector, a positive correlation between average wages and entry should perhaps not be surprising even though we control for lagged employment in the entrant's NAICS-6.

Despite the inclusion of dummy variables for both knowledge center (large research institution) and MSA (urban) county characteristics, both of which would correlate with relatively greater social and cultural opportunities (including spectator sports events), the variable measuring social, cultural, and recreational amenities has a positive and quite significant estimate. The estimate of the coefficient of the proportion of population between the ages of 20 and 44 is also positive and quite significant, if not particularly large in magnitude. In terms of the broader economic conditions prevailing in the county, the softer the regional economy, as expressed in terms of unemployment rates, the less likely it is to observe a start-up.

Among the variables controlling for neighboring county characteristics, three have some statistical significance. It appears that the greater the number of lagged exits in a neighboring county within a given industry, the more likely it is that a start-up will occur. One possible explanation may be that higher exit rates of start-ups are a result of a relatively less supportive entrepreneurial environment. Thus, although 
TABLE 5

(a) Start-up Patterns for Technology Firms (Fixed Effects by 6-Digit NAICS Codes) and (b) Start-up Patterns for Technology Firms in TX Using Dirichelet-Multinomial Model (Group Effects by 6-digit NAICS Codes)

\begin{tabular}{|c|c|c|c|c|}
\hline \multirow[b]{2}{*}{ Variable } & \multicolumn{4}{|c|}{ Number of New Start-ups for a County per Year } \\
\hline & (1) & (2) & (3) & (4) \\
\hline \multicolumn{5}{|l|}{ (a) } \\
\hline \multicolumn{5}{|l|}{ Log of Funding relative to distance to county } \\
\hline Spillover lagged by 1 year & $0.225^{* * *}(0.037)$ & & & \\
\hline Spillover lagged by 2 years & & $0.231^{* * *}(0.038)$ & & \\
\hline Spillover lagged by 3 years & & & $0.243^{* * *}(0.040)$ & \\
\hline Spillover lagged by 4 years & & & & $0.217^{* * *}(0.038)$ \\
\hline \multicolumn{5}{|l|}{ Base county } \\
\hline Knowledge center county & $1.380^{* * *}(0.061)$ & $1.378^{* * *}(0.061)$ & $1.378^{* * *}(0.061)$ & $1.382^{* * *}(0.061)$ \\
\hline MSA county & $1.547^{* * *}(0.092)$ & $1.539^{* * *}(0.090)$ & $1.531^{* * *}(0.088)$ & $1.541^{* * *}(0.089)$ \\
\hline $\begin{array}{l}\text { Log of lagged employment of start-ups } \\
\text { by industry }\end{array}$ & $0.250^{* * *}(0.054)$ & $0.262^{* * *}(0.057)$ & $0.261^{* * *}(0.060)$ & $0.255^{* * *}(0.057)$ \\
\hline $\begin{array}{l}\text { Log of lagged employment of incumbents } \\
\text { by industry }\end{array}$ & $0.355^{* * *}(0.079)$ & $0.360^{* * *}(0.081)$ & $0.361^{* * *}(0.083)$ & $0.358^{* * *}(0.083)$ \\
\hline $\begin{array}{l}\text { Lagged number of exits by start-ups } \\
\text { by industry }\end{array}$ & $-0.012(0.008)$ & $-0.015^{*}(0.008)$ & $-0.019^{* *}(0.008)$ & $-0.017^{*}(0.009)$ \\
\hline $\begin{array}{l}\text { Lagged number of exits incumbents } \\
\text { by industry }\end{array}$ & $0.003(0.004)$ & $0.004(0.004)$ & $0.006(0.004)$ & $0.005(0.004)$ \\
\hline Income (in thousands) & $0.348^{* * *}(0.032)$ & $0.346^{* * *}(0.032)$ & $0.343^{* * *}(0.031)$ & $0.348^{* * *}(0.031)$ \\
\hline Amenity & $0.182^{* * *}(0.018)$ & $0.180^{* * *}(0.019)$ & $0.181^{* * *}(0.019)$ & $0.180^{* * *}(0.019)$ \\
\hline Land price (in hundreds) & $0.084^{* * *}(0.009)$ & $0.085^{* * *}(0.009)$ & $0.087^{* * *}(0.009)$ & $0.087^{* * *}(0.009)$ \\
\hline $\begin{array}{l}\text { Percentage of population between ages } 20 \\
\text { and } 44\end{array}$ & $0.046^{* * *}(0.007)$ & $0.047^{* * *}(0.008)$ & $0.048^{* * *}(0.008)$ & $0.048^{* * *}(0.008)$ \\
\hline Unemployment rate & $-0.142^{* * *}(0.046)$ & $-0.142^{* * *}(0.046)$ & $-0.143^{* * *}(0.046)$ & $-0.149^{* * *}(0.047)$ \\
\hline \multicolumn{5}{|l|}{ Neighboring counties } \\
\hline $\begin{array}{l}\text { Log of lagged employment of start-ups } \\
\text { by industry }\end{array}$ & $-0.075(0.057)$ & $-0.089(0.058)$ & $-0.091(0.063)$ & $-0.084(0.060)$ \\
\hline $\begin{array}{l}\text { Log of lagged employment of incumbents } \\
\text { by industry }\end{array}$ & $-0.071(0.090)$ & $-0.080(0.093)$ & $-0.082(0.095)$ & $-0.079(0.096)$ \\
\hline $\begin{array}{l}\text { Lagged number of exits by start-ups } \\
\text { by industry }\end{array}$ & $0.027^{*}(0.014)$ & $0.031^{* *}(0.014)$ & $0.039^{* *}(0.015)$ & $0.035^{* *}(0.015)$ \\
\hline $\begin{array}{l}\text { Lagged number of exits incumbents } \\
\text { by industry }\end{array}$ & $0.000(0.008)$ & $-0.001(0.007)$ & $-0.004(0.007)$ & $-0.004(0.007)$ \\
\hline Amenity & $-0.126^{* * *}(0.028)$ & $-0.123^{* * *}(0.028)$ & $-0.122^{* *}(0.028)$ & $-0.123^{* *}(0.028)$ \\
\hline $\begin{array}{l}\text { Population percentage between ages } 20 \\
\text { and } 44\end{array}$ & $-0.017^{*}(0.009)$ & $-0.019 *(0.010)$ & $-0.021^{*}(0.010)$ & $-0.021^{* *}(0.010)$ \\
\hline Number of observations & 76,200 & 76,200 & 76,200 & 76,200 \\
\hline Wald $x^{2}$ & $17,272.12$ & $17,299.81$ & $17,302.60$ & $17,280.45$ \\
\hline
\end{tabular}

(b)

Log of Funding relative to distance to county

Spillover lagged by 1 year

Spillover lagged by 2 years

Spillover lagged by 3 years

Spillover lagged by 4 years

$0.241^{* * *}(0.034)$

$0.252^{* * *}(0.033)$

$0.262^{* * *}(0.033)$

\begin{tabular}{|c|c|c|c|c|}
\hline Number of observations & 76,200 & 76,200 & 76,200 & 76,200 \\
\hline Wald $\chi^{2}$ & $9,501.22$ & $9,546.50$ & $9,570.80$ & $9,551.73$ \\
\hline
\end{tabular}

Notes: Estimated coefficients on the five time dummies have been omitted to save space.

Model specification is the same in both $a$ and $b$.

${ }^{* * *}$ Statistical significance at the $1 \%$ level; ${ }^{* *}$ statistical significance at the $5 \%$ level; and *statistical significance at the $10 \%$ level. 
exit rates within a county appear to have a negative influence on the probability of future start-ups in the same county, local entrepreneurs may seek a more supportive adjacent location within the region. The greater the value of the amenity variable in the neighboring county, the lower is the probability of start-up. Amenities, it appears, are also localized at the county level or below and valued by regionally mobile entrepreneurs. Lastly, the greater the proportion of the workforce between 20 and 44 in the neighboring county, the less likely it is to observe a high-tech start-up in the base county. As before, this suggests that high-tech startups, at least at a regional level, gravitate toward localities with relatively younger workforces.

In order to check robustness of our chosen methodology, we re-estimate the same model using the Dirichlet-Multinomial (DM) Regression method with NAICS-6 as group effects. This method was specified by Guimarães and Lindrooth $(2005,2007)$ and also used by Woodward, Figuerido, and Guimarães (2006) as an alternative method to estimate over-dispersed count data models controlling for group heterogeneities. They show that the DM model is a natural extension of McFadden's conditional logit model for grouped data and discuss its use for the case of count models. As can be seen in Table 5(b), with the same specification, results from the DM estimation are consistent with the PQML estimation.

\section{B. Hazard Rates}

Next, we consider hazard rates for all incumbents and start-ups between FY1999-2000 and FY2005-2006. As noted, most previous studies have found that university research positively affects firms that are generally located near universities or research centers. If the effect is greater the closer a firm is to the knowledge center, then hazard rates would be expected to be lower, ceteris paribus, for technology firms located in geographical proximity to knowledge centers and to increase as proximity decreases.

We consider a standard non-parametric Kaplan-Meier (KM) approach to estimate the hazard functions for start-ups and incumbents. In our data set, the average length of survival for start-ups is 27 months. Hence, we track survival up to 36 months. Table 6 provides survival probabilities for start-ups and incumbents. These results clearly show that the hazard rate
TABLE 6

Kaplan-Meier Survival Function Estimates for Start-ups and Incumbents

\begin{tabular}{lcc}
\hline Time & Start-ups & Incumbents \\
\hline 3 months & $0.942(0.003)$ & $0.999(0.000)$ \\
6 months & $0.872(0.004)$ & $0.999(0.000)$ \\
12 months & $0.758(0.005)$ & $0.993(0.001)$ \\
24 months & $0.495(0.006)$ & $0.964(0.002)$ \\
36 months & $0.360(0.006)$ & $0.917(0.003)$ \\
\hline
\end{tabular}

Note: Standard errors are in parenthesis.

for start-ups is substantially higher than the hazard rate for incumbents. After 3 years, the probability of survival for a start-up is only about one-third (36\%) while that of incumbents is $92 \%$.

Note that the KM method is useful for comparing survival curves in two or more groups but it does not control for explanatory factors such as firm size. Cox proportional hazards regression allows analysis of the effect of several risk factors on survival. Using the Cox estimation procedures, we examine the probability of exit for all firms, controlling for start-up status, and for start-up firms only. We control for spillover, MSA, size of the firm, current average wage of the firm, and market conditions. ${ }^{20}$ As a measure of firm size, we use the average ratio of the number of employees in the given firm to the total number of employees in the corresponding 6-digit NAICS in the given county over the period of the firm's operation. The basic Cox proportional hazard model can be written as follows:

$$
h(t \mid z, \psi)=h_{0}(t) \exp \left(z^{\prime} \psi\right)
$$

where $h(t \mid z, \psi)$ is the conditional hazard rate and $h_{0}(t)$ is the unspecified baseline hazard function. The vector of covariates is denoted by $z$ and the corresponding coefficients estimated by the Cox regressions are represented by $\psi$. The predictors are the spillover variables, distance variables, the establishment's current average wage, current relative employment, and market conditions as represented by the monthly prime rate and the state monthly unemployment rate. ${ }^{21}$ The spillover effect is captured by three

20. We also use relative spillover as a variable. Relative spillover for firm $i$ is calculated as the average spillover for given firm $i$ divided by the average spillover for all firms.

21. We used state-level seasonally unadjusted monthly unemployment rates reported by the BLS. 
dummy variables constructed by dividing the range of the distribution of the current spillover that firms experience into four equal intervals and treating membership in the bottom quarter of the range as the omitted group. Distance from the knowledge center is captured by distance dummies constructed in a similar fashion to the spillover dummies. ${ }^{22}$

In columns 1 and 2 of Table 7, Cox proportional hazard regression results are reported for all firms when the dummy variable (startup firm) is included to separate start-ups from incumbents. Column 3 presents results for the Cox regression for start-up firms only.

As expected, in columns 1 and 2, we find that the hazard rate for start-ups is higher than that for incumbents, all else equal. Looking at the spillover dummies and interaction terms, it appears that the spillover has no significant positive effect on the likelihood of survival for either entrants or incumbents. Although the estimated coefficients on the distance variables suggest a weak negative effect on firm survival probability, we find it difficult to imagine that closer proximity to a research institution can increase the likelihood of failure. We do not therefore find this result to be very compelling and assume that another unobservable influence is at work. For example, the greater concentration of firms in these locales may result in a more continuous distribution of firms across risk classes. The results also indicate that the larger the firm, the longer is the expected survival period of the firm. This is consistent with the finding of Dunne, Robert, and Samuelson (1989a, 1989b) that firm size matters.

As Audretsch and Mahmood (1995) found, the wage rate and prime rate are negatively correlated to the hazard rate, whereas the unemployment rate is positively correlated. As they suggest, higher interest rates do not directly affect these firms as they do not rely on bank financing for external capital. Unlike Audretsch and Mahmood, we estimate the hazard model separately for interest rates and unemployment rates because these two variables are highly correlated $(-0.9442)$.

Results for the Cox regression on start-ups only, as reported in column 3 of Table 7, are qualitatively identical to the results for start-ups

22. Note, although we only report results for the distance dummies, we also estimated the model using mileage as described in Section III. Qualitative Cox regression results are the same for both methods of measurement.
FIGURE 2

Hazard Rates for All Start-ups and Incumbents

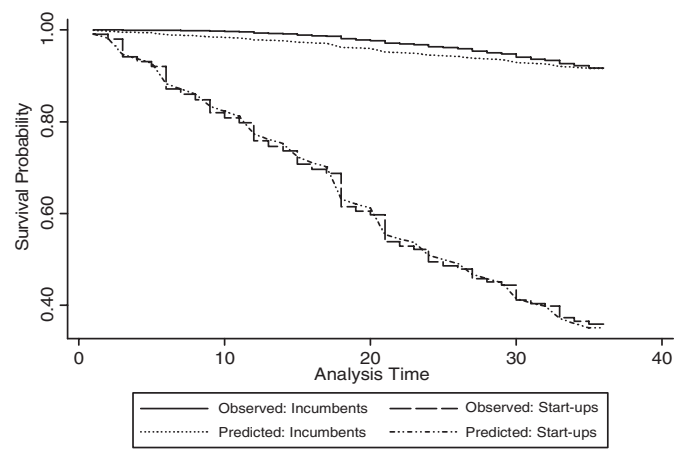

in column 1 . Note, for example, adding the coefficient estimates in column 1 for the spillover dummies and the corresponding estimates for the interaction terms using spillover dummy and start-up dummy yields values nearly equal to the coefficient estimates for spillover in the regression for start-ups only.

The proportional hazards assumption assumes that the hazard ratio is proportional over time. A common method of evaluating the proportional hazards assumption is to plot the KM observed survival curve with the Cox predicted curve and compare. When the two curves, actual and predicted, are close together, the proportional hazards assumption is not violated. From Figure 2, we can clearly see that the two curves are quite similar for both start-ups and incumbents. Note that Figure 2 is drawn after estimating the first column in Table 7. The alternative specification in the second column of Table 7 also shows that the proportional hazards assumption is not violated (figure not provided to save space).

Table 8 provides the distribution of new firms and incumbents by distance. Out of 7,713 hightech firms entering the market between July 1999 and June 2005, about 84\% were located within less than a 50-mile radius from knowledge centers. On the other hand, only about $5.75 \%$ were beyond the 100 -mile radius. Almost identical proportions are observed in incumbents' distribution as well. Although suggestive, this also reflects population distribution.

In Figure 3, we graph the survival patterns for start-ups and incumbents by spillover group. It is clear from this graph that there is a significant difference in survival rates between start-ups and incumbents. However, if either 
TABLE 7

Cox Proportional Hazard Model Estimates for Incumbents and New Start-ups

\begin{tabular}{|c|c|c|c|}
\hline \multirow[b]{2}{*}{ Variable } & \multicolumn{2}{|c|}{ All Firms } & \multirow{2}{*}{$\begin{array}{c}\text { Start-ups } \\
(3)\end{array}$} \\
\hline & (1) & (2) & \\
\hline Start-up firm & $2.875^{* * *}(0.209)$ & $2.869^{* * *}(0.209)$ & \\
\hline Spillover dummy $(25 \%-50 \%)$ & $-0.255(0.271)$ & $-0.234(0.271)$ & $-00.178^{*}(0.096)$ \\
\hline Spillover dummy $(50 \%-70 \%)$ & $0.200(0.194)$ & $0.219(0.194)$ & $-0.050(0.076)$ \\
\hline Spillover dummy $(75 \%-100 \%)$ & $0.201(0.195)$ & $0.225(0.195)$ & $-0.049(0.076)$ \\
\hline Spillover dummy $(25 \%-50 \%) \times$ Start-up firm & $0.080(0.288)$ & $0.052(0.288)$ & \\
\hline Spillover dummy $(50 \%-75 \%) \times$ Start-up firm & $-0.253(0.209)$ & $-0.270(0.209)$ & \\
\hline Spillover dummy $(75 \%-100 \%) \times$ Start-up firm & $-0.252(0.210)$ & $-0.266(0.211)$ & \\
\hline$\leq 50$ miles & $0.306(0.203)$ & $0.303(0.203)$ & $0.193^{* *}(0.083)$ \\
\hline$>50$ to $\leq 75$ miles & $0.189(0.235)$ & $0.184(0.235)$ & $0.099(0.097)$ \\
\hline$>75$ to $\leq 100$ miles & $-0.259(0.317)$ & $-0.261(0.317)$ & $-0.023(0.103)$ \\
\hline$\leq 50$ miles $\times$ Start-up firm & $-0.132(0.219)$ & $-0.127(0.220)$ & \\
\hline$>50$ to $\leq 75$ miles $\times$ Start-up firm & $-0.095(0.256)$ & $-0.081(0.256)$ & \\
\hline$>75$ to $\leq 100$ miles $\times$ Start-up firm & $0.243(0.334)$ & $0.252(0.334)$ & \\
\hline Employment ratio & $-0.162^{* *}(0.059)$ & $-0.171^{* *}(0.059)$ & $-0.076(0.061)$ \\
\hline Log of wage & $-0.144^{* * *}(0.017)$ & $-0.151^{* * *}(0.017)$ & $-0.140^{* * *}(0.018)$ \\
\hline Unemployment rate & $0.488^{* * *}(0.023)$ & & $0.455^{* * *}(0.023)$ \\
\hline Prime rate & & $-0.238^{* * *}(0.019)$ & \\
\hline Number of observations & 17,152 & 17,152 & 7,713 \\
\hline Wald $\chi^{2}$ & $5,164.664$ & $4,660.052$ & 515.989 \\
\hline
\end{tabular}

Notes: Robust standard errors are in parentheses.

*** Statistical significance at the $1 \%$ level; ${ }^{* *}$ statistical significance at the $5 \%$ level; and *statistical significance at the $10 \%$ level.

TABLE 8

Distribution of Start-ups and Incumbents by Distance to Knowledge Centers

\begin{tabular}{lcc}
\hline Distance & Start-ups & Incumbents \\
\hline$\leq 50$ miles & 6,479 & 7,866 \\
$>50$ to $\leq 75$ miles & 513 & 744 \\
$>75$ to $\leq 100$ miles & 278 & 297 \\
$>100$ miles & 443 & 532 \\
\hline
\end{tabular}

group is considered separately, distance does not have any apparent effect on the within-group survival rates. This is consistent with the results reported in Table 8.

As discussed above, if knowledge spillovers represent positive external economies to technology firms located close to the location of the R\&D activity, hazard rates would be expected to be lower, ceteris paribus, for technology firms located in geographical proximity to knowledge centers and to increase as proximity decreases. Figure 4 illustrates hazard rates for start-ups and incumbents by the minimum distance to knowledge centers. Again, from these graphs, it is clear that there is a significant difference in survival rates for start-ups and incumbents.
However, as in the previous graphs, within groups, there is little apparent effect on hazard rates from distance to the knowledge center. For new start-up firms within the 50-mile radius, the survival rate is about $35 \%$ after 36 months compared to a rate above $90 \%$ for incumbents.

Note that our current definition of start-ups limits the period of analysis. For example, we may observe a firm entering the market in May of 2005. But as our data set ends in June of 2005, the KM Survival Function Estimates would treat this firm as existing only 1 month before exit, as all firms appear to terminate with the end of the data in June, 2005. By including these late entries, there would be a tendency to underestimate the survival rates for new firms. To overcome this problem, we change our set of observations on start-ups to include only those firms that can be tracked for at least 3 years. We drop from the sample all firms that entered after 36 months before the end of the data, i.e., any firm that entered after June 2002. Hence, we treat as a start-up any firm that entered the market between July 1999 and June 2002 and trace their existence for 3 years from the date of start-up. To be consistent with the new firm definition, we treat an incumbent as a firm that 
FIGURE 3

Hazard Rates for New Start-ups and Incumbents by Spillover
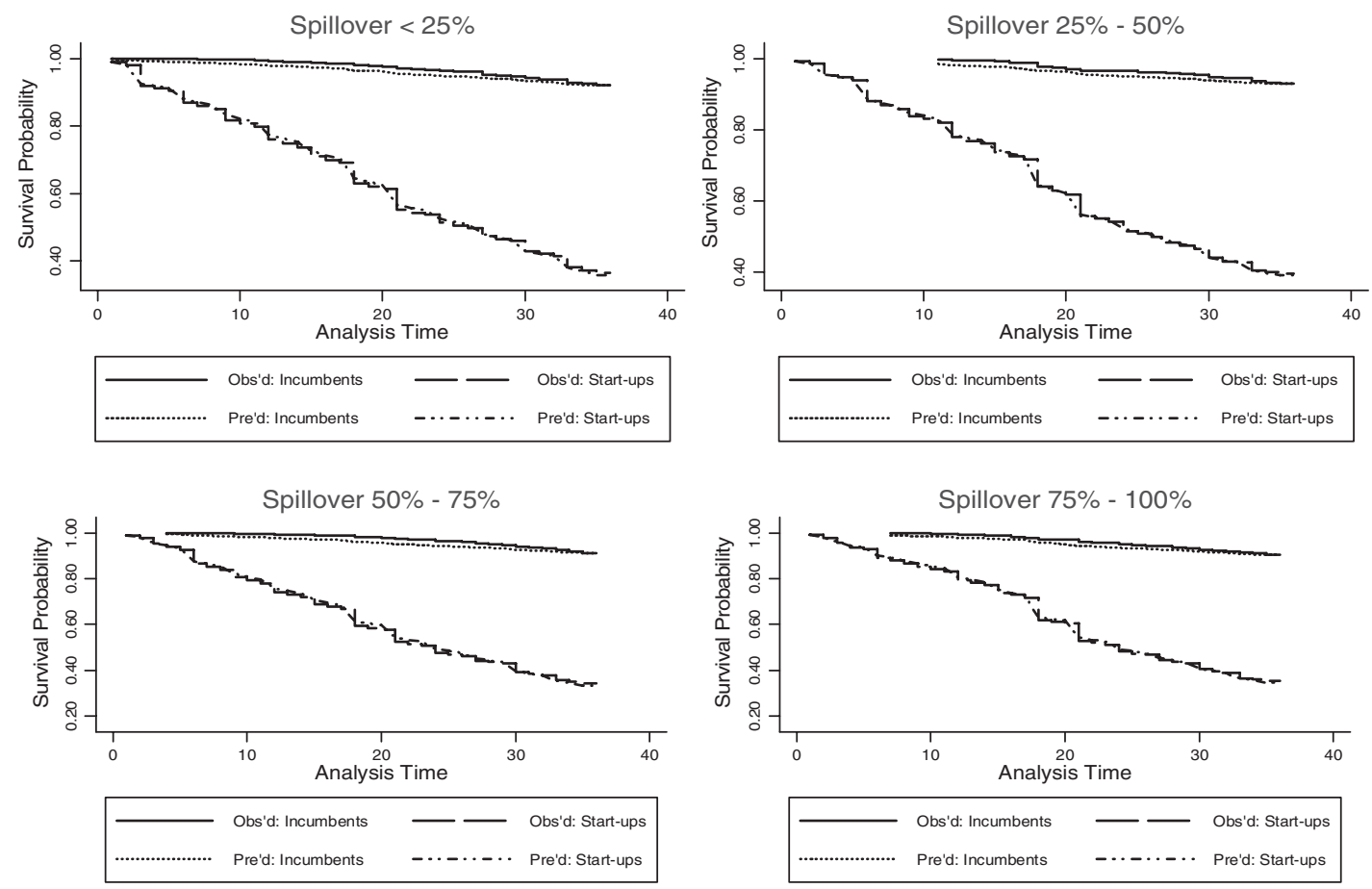

entered the market before July 1996. Firms that entered the market between July 1996 and June 1999 will be dropped as they will not have already survived at least 36 months. Hazard rates for all start-ups and incumbents under the alternative definitions are illustrated in Figure 5. To economize on space, we provide only the graphical results.

Even with our alternative definition, our qualitative results do not change although the magnitude of survival of new firms has increased. This would be expected with our new definitions. This qualitative result is true for all above estimated hazard rates.

\section{CONCLUSION}

The intent in this study was to consider the localized influence of university $R \& D$ on the likelihood of firm start-up and survival. In the case of start-ups, our assumption is that, if a localized spillover is present, it will be expressed in a higher likelihood of observing new firms in the knowledge-intensive or hightech industries in areas more proximate to the university. As suggested at the outset of this

article, the knowledge spillovers are most easily pictured for us in the form of start-ups based on intellectual properties that result either directly from the research or as variations or derivatives of that research. This would be the case if, for example, the research results and implications are diffused locally through informal networks before the research outcomes are made widely public.

Although otherwise controlling for the qualitative effect of the presence of a research institution, we find evidence that both the size of the research enterprise and its relative proximity help to explain the likelihood of start-ups in a locality (county). This is consistent with the hypothesis that specific knowledge spillovers are present. As distance to the knowledge center increases, for a given level of university $\mathrm{R} \& \mathrm{D}$, the likelihood of a start-up decreases. Computing marginal effects (for column 1 in Table 5(a)), we estimate that a $1 \%$ increase in the distance from the knowledge center, all else equal, will result in a $0.119 \%$ decrease in the likelihood of observing a start-up in a given county. This also suggests a relatively 


\section{FIGURE 4}

Hazard Rates for New Start-ups and Incumbents by Distance
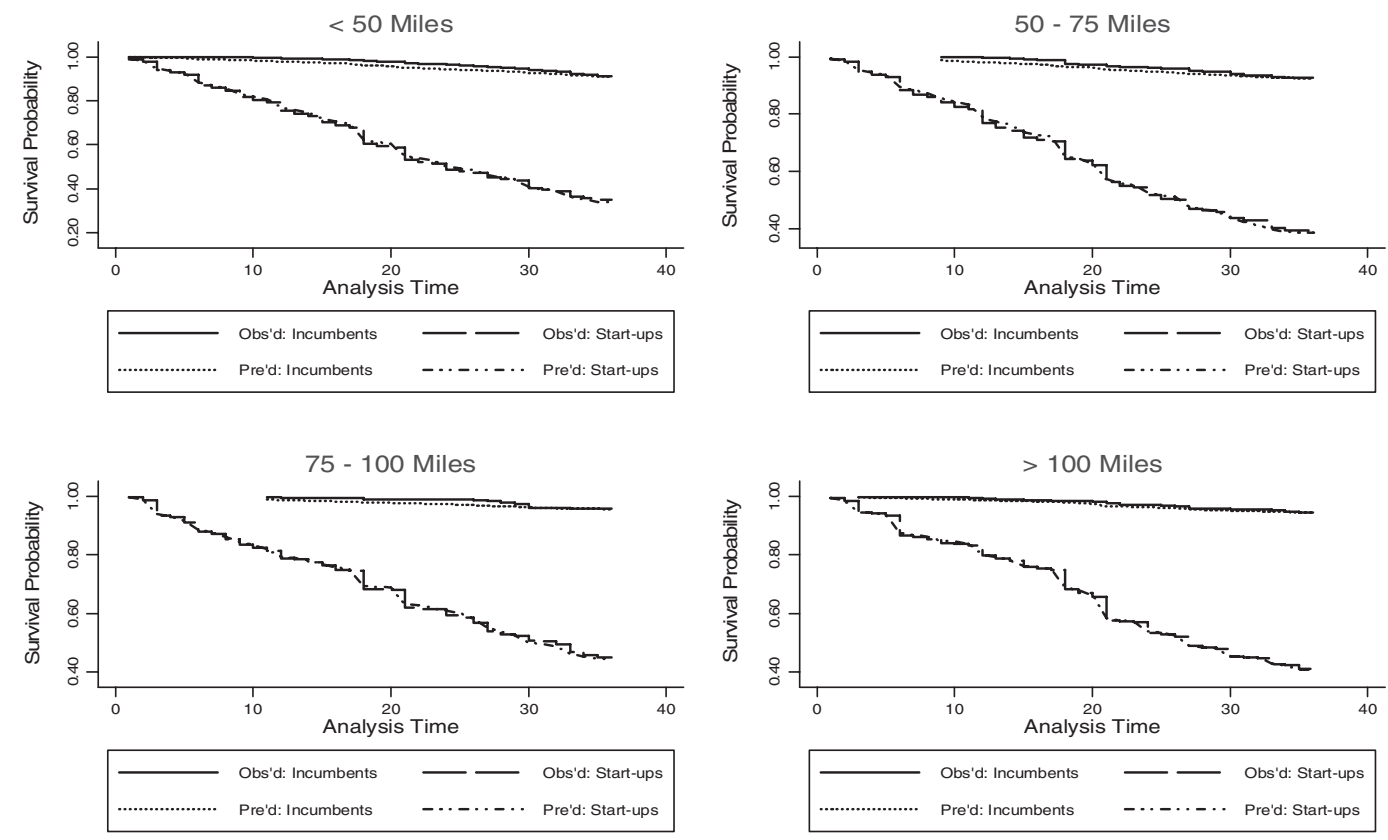

FIGURE 5

Hazard Rates for all Start-ups and Incumbents with Alternative Definition

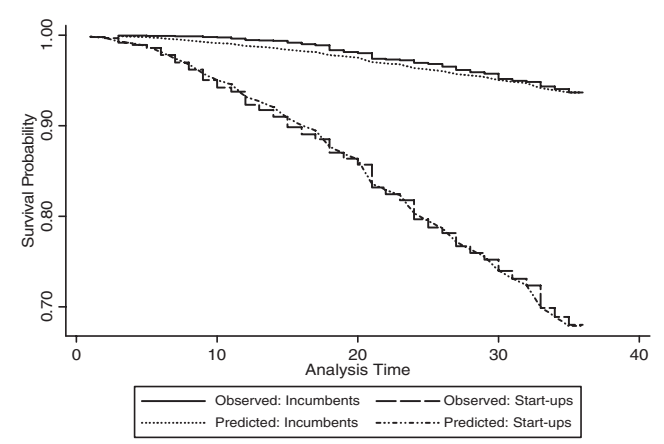

sharp diminution in the likelihood of observing a start-up as distance from the knowledge center increases, for any given level of R\&D funding. This finding is consistent with previous research on the question (Woodward, Figuerido, and Guimarães 2006). Other factors appear to be more important than the level of $R \& D$ funding. Specifically, other localized non-research elements embodied in the presence of the university and the area's metropolitan characteristics have a greater effect.
The question of the effect of university $R \& D$ in the case of firm survival is somewhat different from that of entry. A start-up firm based on intellectual property that devolves from or is motivated by university research may or may not benefit directly from continued proximity to the ongoing university research after the firm is actually launched. One can easily imagine an entrepreneur enlightened by the university research who then conceives an innovative idea, starts a firm, and is off and running on his/her own. On the other hand, continued localized benefits in the form of technical knowledge resources (brown bags, libraries, and easily accessible faculty consultants), related ongoing research, or a greater pool of skilled labor will extend competitive advantages to nearby firms. If so, firms located in closer proximity to the knowledge center should exhibit higher survival rates than more distant firms with reduced access to these economies.

We find weak evidence that hazard rates for start-ups are positively influenced by proximity to the knowledge centers. The question we have posed is whether or not knowledge spillovers from university $R \& D$ reduce hazard rates. The results of this analysis, then, suggest that beneficial spillovers are not present or 
that spillovers, if present, do not enhance the likelihood of firm survival regardless of distance from the knowledge center. Given the persuasive results on entry, the conclusion, based on the hazard model, that spillovers are not present is not very compelling on its surface.

One plausible explanation for this finding is, as noted above, that the local availability of the R\&D spillovers motivates higher frequency of start-up in the industries for which the spillovers are a production input. With higher frequency of start-up within a relatively narrow, locally differentiated product space, competition among local firms would likely be greater. Indeed, one would expect to observe entry up to the point at which the private benefits of the jointly consumed spillover are eliminated. The net effect would be that failure rates would be similar across the broader region. It is also possible that there are both economies and diseconomies associated with locating within growing concentrations of technology firms. Firms would be advantaged by the localized spillovers up to the point at which they are offset by diseconomies as a result of the increasing geographical concentration. One example of such a diseconomy might be a dilution of managerial competence if the regional supply of competent technology business managers is inelastic.

Hazard rates for start-up firms are, of course, significantly higher than that for incumbent firms. Consistent with the findings of Dunne, Robert, and Samuelson (1989a), we find that larger firms are more likely to survive. Market conditions also appear to matter insofar as the unemployment rate has a positive and significant effect on hazard rates.

One further conclusion that might be drawn from these results is that even if observed hazard rates are not lower among technology firms located near research centers, the research institutions can make a contribution to regional economic activity by inspiring higher rates of start-up activity. That is, higher rates of startup activity at similar hazard rates will result in higher levels of technology industry employment in the regions around knowledge centers. Moreover, as the presence of technology firms is also a factor in explaining technology start-up activity, the growth in technology firm startups should accelerate relative to other regions through time.

\section{REFERENCES}

Abramovsky, L., R. Harrison, and H. Simpson. "University Research and the Location of Business R \& D." The Economic Journal, 117, 2007, C114-41.

Acs, Z. J., L. Anselin, and A. Varga. "Patents and Innovation Counts as Measures of Regional Production of New Knowledge." Research Policy, 3, 2002, 1069-85.

Acs, Z. J., D. B. Audretsch, and M. P. Feldman. "R\&D Spillovers and Recipient Firm Size." Review of Economics and Statistics, 76, 1994, 336-40.

_. "Real Effects of Academic Research: Comment." American Economic Review, 82, 1992, 363-67.

Anselin, L., A. Varga, and Z. J. Acs. "Geographical Spillovers and University Research: A Spatial Econometric Perspective." Growth and Change, 31, 2000, 501-15.

Audretsch, D. B., and M. P. Feldman. "R\&D Spillovers and the Geography of Innovation and Production." American Economic Review, 86, 1996, 630-40.

Audretsch, D. B., and T. Mahmood. "New Firm Survival: New Results Using a Hazard Function." The Review of Economics and Statistics, 77, 1995, 97-103.

AUTM. "Licensing Survey." 2004. http://www.autm.org/ events/File/FY04\%20Licensing\%20Survey/04AUTM USLicSrvy-public.pdf

Baldwin, J. R., and P. K. Gorecki. "Firm Entry and Exit in the Canadian Manufacturing Sector, 1970-1982." The Canadian Journal of Economics, 24, 1991, 300-23.

Cameron, C. A., and P. K. Trivedi. "Microeconometrics: Methods and Applications." New York: Cambridge University Press, 2005.

Carlino, G. A., and A. Saiz. "City Beautiful." The Federal Reserve Bank of Philadelphia. Working Paper No. 08-22, 2008.

Chapple, K., A. Markusen, G. Schrock, D. Yamamoto, and P. Yu. "Gauging Metropolitan High-Tech and "I-Tech" Activity." Economic Development Quarterly, 18, 2004, 10-29.

Dunne, T., S. D. Klimek, and M. J. Roberts. "Exit from Regional Manufacturing Markets: The Role of Entrant Experience." International Journal of Industrial Organization, 23, 2005, 399-421.

Dunne, T., M. J. Robert, and L. Samuelson. "Patterns of Firm Entry and Exit in U.S. Manufacturing Industries." The Rand Journal of Economics, 19, 1988, 495-515.

Dunne, T., M. J. Robert, and L. Samuelson. "The Growth and Failure of U.S. Manufacturing Plants." The Quarterly Journal of Economics, 104, 1989a, 671-98.

. "Firm Entry and Postentry Performance in the US Chemical Industry." Journal of Law and Economics, 32, 1989b, 233-71.

Fischer, M. M., and A. Varga. "Spatial Knowledge Spillovers and University Research: Evidence from Austria." The Annals of Regional Science, 37, 2003, 303-22.

Glaeser, E. L., J. Kolko, and A. Saiz. "Consumer City." Journal of Economics Geography, 1, 2001, 27-50.

Gourieroux, C., A. Montfort, and A. Trognon. "Pseudo Maximum Likelihood Methods: Theory." Econometrica, 52, 1984a, 681-700.

. "Pseudo Maximum Likelihood Methods: Application to Poisson Models." Econometrica, 52, 1984b, $701-21$.

Guimarães, P. "The Fixed Effects Negative Binomial Model Revisited." Economics Letters, 99, 2008, 63-66.

Guimarães, P., and R. Lindrooth. "Controlling for Overdispersion in Grouped Conditional Logit Models: A Computationally Simple Application of Dirichlet Multinomial Regression." Econometrics Journal, 10, 2007, 439-52. 
"Dirichlet-Multinomial Regression." RePEc Working Paper No. 0509001, 2005.

Jaffe, A. B. "Real Effects of Academic Research." American Economic Review, 79, 1989, 957-70.

Jaffe, A. B., M. Trajtenberg, and R. Henderson. "Geographic Localization of Knowledge Spillovers as Evidenced by Patent Citations." The Quarterly Journal of Economics, 108, 1993, 577-98.

Mansfield, E. "Academic Research Underlying Industrial Innovations: Sources, Characteristics, and Financing." Review of Economic and Statistics, 77, 1995, 55-65.

Nelson, R. "Institutions Supporting Technical Advance in Industry." American Economic Review, 76, 1986, $186-89$.

Paytas, J., and D. Berglund. "Technology Industries and Occupations for NAICSIndustry Data." Pittsburgh: Carnegie Mellon Center for Economic Development and State Science and Technology Institute, 2004. http://www.ssti.org/Publications/Onlinepubs/NAICS_ Tech1.pdf

Paytas, J., R. Gradeck, and L. Andrews. "Universities and the Development of Industry Clusters." CarnegieMellon Center for Economic Development, U.S. Economic Development Administration, 2004.

Woodward, D., O. Figuerido, and P. Guimarães. "Beyond the Silicon Valley: Univeristy $R \& D$ and High
Technology Location." Journal of Urban Economics, 60, 2006, 15-32.

Wooldridge, J. Econometric Analysis of Cross Section and Panel Data. Cambridge, MA, MIT Press, 2002.

Zucker, L. G., M. R. Darby, and M. B. Brewer. "Intellectual Human Capital and the Birth of U.S. Biotechnology Enterprises." American Economic Review, 88, 1998, 290-306.

\section{SUPPORTING INFORMATION}

Additional Supporting Information may be found in the online version of this article:

Table S1. High-tech industry classifications.

Table S2. Academic institutions by county.

Please note: Wiley-Blackwell are not responsible for the content or functionality of any supporting materials supplied by the authors. Any queries (other than missing material) should be directed to the corresponding author for the article. 